\title{
12. X-RAY MINERALOGY OF DSDP LEGS 44 AND 44A, WESTERN NORTH ATLANTIC: LOWER CONTINENTAL RISE HILLS, BLAKE NOSE, AND BLAKE-BAHAMA BASIN
}

\author{
Roger D. Flood, Woods Hole Oceanographic Institution, Woods Hole, Massachusetts, \\ and Massachusetts Institute of Technology, Cambridge, Massachusetts
}

\section{METHODS}

Bulk samples were analyzed with an X-ray diffractometer in order to obtain semiquantitative determinations of the mineral composition of the sediments sampled. The analyses were performed in the manner of Cook et al., 1975.

Briefly, the method was as follows. Bulk samples were washed with distilled water to remove sea salts and ground to less than $10 \mu \mathrm{m}$ under butanol. They were then treated with trihexylamine acetate to expand smectite minerals and $\mathrm{X}$-rayed as random powders. Bulk samples were subjected to $\mathrm{Cu}-\mathrm{K} \alpha$ radiation at $2^{\circ}$ $2 \theta /$ minute. A $1^{\circ}$ divergence slit and a 0.001 inch receiving slit with a curved crystal monocromator were used. Diffraction patterns were recorded on chart paper at $1 \mathrm{inch} /$ minute with a full-scale reading of 1000 counts per second. Due to equipment failures and time constraints, three different X-ray diffraction units were used during the course of this study. Identical samples run on all three machines showed relative peak intensities which were within the limits of the technique. Standard rate-meter techniques were used with a time constant of 0.5 second.

Mineral identifications were made manually on the basis of a peak present within one of the windows indicated by Cook et al., 1975, and verified by the presence of secondary peaks. Diffraction traces were manually smoothed and the diagnostic peak heights were measured. Secondary peaks were used to calculate the diagnostic peak height if the diagnostic peak was off-scale. Peak heights were corrected for interfering peaks of other minerals present in the sample, and mineral weights were calculated by the method of mutual ratios (Cook et al., 1975). The total of all minerals identified was set equal to $100 \%$ and relative mineral composition computed with abundances reported to the nearest percent. The amount of amorphous material was not determined quantitatively.

Several factors combine to limit the accuracy and precision of the measurements made here. The limitation on accuracy is mainly in the use of the weighting factors (derived by Cook et al., 1975). As they pointed out, these factors were determined by ratioing the diagnostic peak of the mineral in question to the major quartz peak in mixtures of known composition. Differences in crystallinity between the mineral standards and the mineral samples and the interference from other diffraction peaks often keep the accuracy of the method below the implied precision. Zemmels and Cook (1976) reported that the errors could be as much as $\pm 50 \%$ for smectites; $\pm 20 \%$ for micas, chlorites, cristobalite, tridymite, and goethite; $\pm 10 \%$ for kaolinite, amphibole, augite, feldspar, zeolite, palygorskite, sepiolite, and apatite and $\pm 5 \%$ for minerals which have stable crystal lattices and are not members of solid solution series (or typically have limited crystal-lattice substitution in the sedimentary environment) such as quartz, low-magnesian calcite, aragonite, dolomite, rhodochrosite, siderite, gibbsite, talc, barite, anatase, gypsum, anhydrite, halite, pyrite, hematite, and magnetite.

Strictly speaking, the weighting factors are only valid when used with the X-ray diffraction system for which they were derived. However, because of the similarity of the instruments involved, these factors were applied in this work. The use of these weighting factors, as well as the use of three X-ray diffraction units during the course of the study, also reduce the accuracy below the implied precision.

The sensitivity of the method is limited mainly by the effectiveness of the random background noise in masking the diagnostic and secondary peaks of a mineral. In general, a mineral has to comprise $1 \%-2 \%$ of a sample before it will be recorded on an X-ray diffractogram.

In using these data one should bear in mind that the reported values are not absolute concentrations, i.e., some adjustment must be made for the amount of amorphous material and any unquantified minerals. Moreover, the trends seen within a homogeneous set of minerals are valid, but, in order to compare mineral concentrations between lithologic units or geographical regions, information on the crystallinity is required.

\section{RESULTS}

\section{Site 388}

Hole $388 \mathrm{~A}$ was drilled in the lower continental rise hills found at the base of the continental rise on the western Atlantic continental margin. The purpose of this hole was to determine the origin of these hills. Two sedimentary units were recognized by the shipboard scientists. Table 1 summarizes the X-ray diffraction data for this hole.

\section{Unit 1}

Unit 1 consists of Recent to lower Pleistocene terrigenous sediments ranging from coarse sand and silty clay to clay. Five samples were $\mathrm{X}$-rayed from this unit. Carbonates are present with calcite comprising $16 \%-42 \%$ of the samples and dolomite accounting for 
TABLE 1

X-Ray Mineralogy Summary, Hole 388A

\begin{tabular}{|c|c|c|c|c|c|c|c|c|c|c|c|c|c|c|c|}
\hline $\begin{array}{c}\text { Sample } \\
\text { (Interval in } \mathrm{cm} \text { ) }\end{array}$ & $\begin{array}{l}\text { Depth } \\
\text { (m) }\end{array}$ & Unit & $\frac{\dot{0}}{\text { तु }}$ & $\frac{0}{\circ}$ & : & 氙 & 章 & 㫯 & 异 & $\stackrel{\vec{E}}{\Sigma}$ & $\begin{array}{l}\dot{0} \\
\ddot{g}\end{array}$ & हี & 㝴 & 苂 & 完 \\
\hline $1-3,99-101$ & 4.0 & 1 & 41 & 2 & - & 29 & 6 & 12 & 6 & - & 3 & - & - & - & - \\
\hline $1-4,100-102$ & 5.5 & 1 & 23 & 2 & - & 43 & 11 & 12 & 8 & - & 2 & - & - & - & - \\
\hline $2-1,126-128$ & 38.3 & 1 & 22 & 2 & - & 27 & 14 & 21 & 8 & - & 3 & - & - & 2 & 2 \\
\hline $2-2,99-101$ & 39.5 & 1 & 42 & 1 & - & 31 & 6 & 9 & 6 & - & 3 & - & - & 3 & - \\
\hline $2-3,100-102$ & 41.0 & 1 & 16 & 1 & - & 33 & 5 & 8 & 23 & - & 10 & 2 & - & 3 & - \\
\hline $5-1,100-102$ & 247.0 & 2 & - & - & - & 43 & 8 & 9 & 19 & 4 & 8 & 2 & 6 & - & - \\
\hline $5-3,100-102$ & 250.0 & 2 & - & - & - & 47 & 7 & 7 & 19 & 10 & 8 & 3 & - & - & - \\
\hline $5-6,88-90$ & 254.4 & 2 & - & - & - & 53 & 8 & 7 & 16 & 5 & 7 & - & - & 3 & - \\
\hline $6-2,90-91$ & 286.4 & 2 & 15 & - & 30 & 25 & - & - & 10 & 10 & - & - & - & 11 & - \\
\hline $7-2,99-101$ & 296.0 & 2 & - & - & - & 66 & 4 & 6 & 14 & 5 & 5 & $\overline{0}$ & - & - & - \\
\hline $7-3,104-106$ & 297.6 & 2 & - & - & - & 49 & 7 & 12 & 15 & 8 & 6 & 3 & - & - & - \\
\hline $8-1,108-110$ & 304.1 & 2 & - & - & 2 & 43 & 6 & 9 & 24 & 9 & 6 & - & - & - & - \\
\hline $9-3,108-110$ & 316.6 & 2 & - & - & 3 & 42 & 7 & 10 & 21 & 10 & 7 & - & - & - & - \\
\hline $9-4,42-44$ & 317.4 & 2 & 11 & - & - & 35 & 7 & 7 & 19 & 9 & 9 & - & - & 3 & - \\
\hline $9-5,68-70$ & 319.2 & 2 & - & - & 1 & 62 & 6 & 5 & 15 & 5 & 5 & - & - & - & - \\
\hline $10-1,128-130$ & 323.3 & 2 & - & - & 1 & 42 & 9 & 8 & 24 & 9 & 8 & - & - & - & - \\
\hline $11-2,12-14$ & 333.1 & 2 & 28 & - & 4 & 28 & 5 & 8 & 15 & 5 & 6 & - & - & - & - \\
\hline $11-2,26-28$ & 333.3 & 2 & 2 & - & 3 & 48 & 6 & 9 & 18 & 6 & 8 & - & - & - & - \\
\hline
\end{tabular}

$1 \%-2 \%$. Silicate minerals are abundant with quartz accounting for $27 \%-43 \%$, total feldspar for $13 \%-35 \%$, clay minerals for $9 \%-33 \%$, and amphibole $(0 \%-2 \%)$ is present in trace amounts. Plagioclase (8\%-21\%) is more abundant than $\mathrm{K}$-feldspar (5\%-14\%), and mica (6\%$23 \%)$ is the dominant clay mineral with kaolinite $(2 \%$ $10 \%)$ secondary and chlorite $(0 \%-2 \%)$ present in trace amounts. The major peak for hematite was seen $(0 \%$ $3 \%$ ) but no secondary peaks were detected.

\section{Unit 2}

Unit 2 is late to middle Miocene clay and silty clay. Thirteen samples were analyzed from this unit. Carbonate minerals present are calcite $(0 \%-28 \%)$ and siderite $(0 \%-4 \%)$. Silicates include quartz $(28 \%-66 \%)$, feldspars (10\%-19\%), and clay minerals (21\%-40\%). Plagioclase (5\%-12\%) and K-feldspar (4\%-9\%) are almost equally abundant, and mica is the dominant clay mineral (10\%-24\%) with montmorillonite (4\%$10 \%)$, kaolinite (0\%-9\%), and chlorite (0\%-3\%) also present. Pyrite was seen to form $6 \%$ of one sample. A siderite nodule at Sample 6-2, 90-91 cm contained 15\% calcite, $30 \%$ siderite, $25 \%$ quartz, $10 \%$ mica, $10 \%$ montmorillonite, and $11 \%$ hematite. Hematite (0\%-3\%) was also scattered throughout this unit.

\section{Site 390}

Holes 390 and 390A were drilled on the Blake Nose to study the Cretaceous reef complex and the overlying Tertiary sequence. Eight lithologic units were recognized by the shipboard scientists. No samples from unit 1 were analyzed. Tables 2 and 3 summarize the Xray diffraction data from these two holes.

\section{Unit 2}

Unit 2 is zeolitic, white nannofossil ooze of middle Eocene age. The five samples of this unit which were Xrayed showed $98 \%-99 \%$ calcite, $1 \%$ quartz, and $0 \%-1 \%$ clinoptilolite.
TABLE 2

X-Ray Mineralogy Summary, Hole 390

\begin{tabular}{|c|c|c|c|c|c|c|c|c|}
\hline $\begin{array}{c}\text { Sample } \\
\text { (Interval in } \mathrm{cm} \text { ) }\end{array}$ & $\begin{array}{l}\text { Depth } \\
\text { (m) }\end{array}$ & Unit & गु & हैं & 荘 & $\frac{\mathscr{m}}{20}$ & $\stackrel{\text { 률 }}{\Sigma}$ & 刕 \\
\hline $1-2,126-128$ & 2.8 & 2 & 99 & 1 & - & - & - & - \\
\hline $3-2,89-91$ & 135.4 & 7 & 41 & 23 & 8 & 10 & 14 & 4 \\
\hline $3-3,70-72$ & 136.7 & 7 & 68 & 12 & 3 & 5 & 10 & 2 \\
\hline $4-1,136-138$ & 143.9 & 7 & 49 & 18 & 7 & 11 & 13 & 2 \\
\hline $4-2,89-91$ & 144.9 & 7 & 58 & 14 & 5 & 7 & 14 & 2 \\
\hline $5-2,78-79$ & 154.3 & 7 & 86 & 3 & 2 & 2 & 5 & 1 \\
\hline $9-1,96-98$ & 191.0 & 8 & 100 & - & - & - & - & - \\
\hline
\end{tabular}

\section{Unit 3}

Unit 3 is pale brown and yellow nannofossil ooze of middle Eocene to middle Paleocene age which has been broken into two sub-units. Sub-unit $3 a$ is siliceous nannofossil ooze which shows, in four samples, 97\%$99 \%$ calcite, $1 \%-2 \%$ quartz, and $0 \%-1 \%$ clinoptilolite. Sub-unit $3 \mathrm{~b}$ is cherty nannofossil limestone which, in two samples, is $93 \%-95 \%$ calcite, $4 \%-6 \%$ quartz and, $1 \%$ clinoptilolite.

\section{Unit 4}

Unit 4 is Danian zeolitic nannofossil ooze which, in three samples, is $93 \%-95 \%$ calcite, $3 \%-4 \%$ quartz, $0 \%$ $3 \%$ mica, and $0 \%-1 \%$ clinoptilolite.

\section{Unit 5}

Unit 5 is Maestrichtian nannofossil ooze. Three samples in the marly upper part of this unit (sub-unit 5a) show $93 \%-97 \%$ calcite, $3 \%$ quartz, 0\%-2\% Kfeldspar, and $0 \%-2 \%$ mica. Two samples in the homogeneous, higher carbonate sub-unit (5b) show $98 \%-99 \%$ calcite, $1 \%$ quartz, and 0\%-2\% K-feldspar.

\section{Unit 6}

One sample in unit 6, Maestrichtian-Campanian nannofossil ooze has $99 \%$ calcite and $1 \%$ quartz. 
TABLE 3

X-Ray Mineralogy Summary, Hole 390A

\begin{tabular}{|c|c|c|c|c|c|c|c|}
\hline $\begin{array}{c}\text { Sample } \\
\text { (Interval in } \mathrm{cm} \text { ) }\end{array}$ & $\begin{array}{l}\text { Depth } \\
\text { (m) }\end{array}$ & Unit & हु่ & $\stackrel{\text { ڤే }}{3}$ & $\frac{0}{\dot{3}}$ & $\stackrel{\text { J }}{\sum}$ & 豆 \\
\hline $1-1,124-126$ & 10.8 & 2 & 98 & 1 & - & - & 1 \\
\hline $2-2,93-95$ & 21.4 & 2 & 99 & 1 & - & - & - \\
\hline $3-2,100-102$ & 31.0 & 2 & 99 & 1 & - & - & - \\
\hline $4-4,73-75$ & 43.2 & 2 & 99 & 1 & - & - & - \\
\hline $5-2,88-90$ & 49.9 & $3 \mathrm{a}$ & 97 & 1 & - & - & 1 \\
\hline $6-1,104-106$ & 58.1 & $3 a$ & 99 & 1 & - & - & - \\
\hline $6-4,115-117$ & 62.7 & $3 a$ & 99 & 1 & - & - & - \\
\hline $7-4,41-43$ & 71.4 & $3 a$ & 99 & 2 & - & - & - \\
\hline $8-2,108-110$ & 78.6 & $3 b$ & 95 & 4 & - & - & 1 \\
\hline $9-1,136-138$ & 86.9 & $3 b$ & 93 & 6 & - & - & 1 \\
\hline $10-1,113-115$ & 96.1 & 4 & 95 & 4 & - & - & 1 \\
\hline $10-2,15-17$ & 96.7 & 4 & 93 & 3 & - & 3 & 1 \\
\hline $11-2,106-108$ & 107.1 & 4 & 94 & 4 & - & 2 & - \\
\hline $11-6,114-116$ & 113.1 & $5 \mathrm{a}$ & 95 & 3 & - & 2 & - \\
\hline $12-4,100-102$ & 119.5 & $5 \mathrm{a}$ & 97 & 3 & - & - & - \\
\hline $12-6,101-103$ & 122.5 & $5 \mathrm{a}$ & 93 & 3 & 2 & 1 & - \\
\hline $13-2,113-115$ & 126.1 & $5 b$ & 98 & 1 & 2 & - & - \\
\hline $13-6,95-97$ & 132.0 & $5 b$ & 99 & 1 & - & - & - \\
\hline $14-4,97-99$ & 138.5 & 6 & 99 & 1 & - & - & - \\
\hline
\end{tabular}

\section{Unit 7}

Unit 7 is a variegated marly nannofossil ooze of Aptian, Albian, and Barremian? age. Five samples from different lithologies were analyzed. The range of calcite is from $86 \%$ in a nannofossil chalk to $41 \%$ in a clay layer. Respective variations in other minerals are $3 \%-23 \%$ for quartz, $4 \%-18 \%$ for feldspars (plagioclase $2 \%-11 \%$, K-feldspar $2 \%-8 \%$ ), and $6 \%-18 \%$ for clay minerals (mica $5 \%-14 \%$, kaolinite $1 \%-4 \%$ ).

\section{Unit 8}

Unit 8, a Barremian or older limestone, was found on the basis of one sample of Core $390-9$, to be $100 \%$ calcite.

\section{Site 391}

Holes 391, 391A, 391 B, and 391C were drilled in the Blake-Bahama Basin. Hole 394A was drilled at this site on Leg 44A. The X-ray results of samples from Hole $394 \mathrm{~A}$ are discussed later. Shipboard scientists distinguished five major lithologic units extending in age from Quaternary to early Tithonian. These units have been further divided into a total of 14 sub-units. Tables 4 through 7 summarize the X-ray diffraction data from these four holes.

\section{Unit 1}

Unit 1 is a Quaternary silty clay. Nine samples were $\mathrm{X}$-rayed and carbonate minerals range between $12 \%$ $37 \%$ for calcite and $2 \%-4 \%$ for dolomite. Aragonite (11\%) was seen in Sample 391A-1-5, 91-93 cm. Quartz ranges from $22 \%$ to $43 \%$, total feldspar from $12 \%$ to $30 \%$, total clay minerals from $20 \%$ to $39 \%$, and amphibole from $0 \%$ to $3 \%$. Plagioclase $(8 \%-26 \%)$ is more abundant than $\mathrm{K}$-feldspar (4\%-13\%). Clay minerals present are mica $(8 \%-26 \%)$, kaolinite (2\%-8\%), chlorite (0\%-6\%), and montmorillonite (0\%-2\%). Pyrite (1\%) was detected in one sample.

\section{Unit 2}

Unit 2 is a complex unit including zones of intraclastic chalk, mudstone, and carbonate silt of early to late Miocene age. This unit has been broken into five sub-units. Sub-unit $2 a$ is a white calcareous silt. Two samples of this sub-unit were X-rayed which showed the chalk to be composed entirely of carbonate minerals. The carbonate mineral composition is $48 \%$ $52 \%$ calcite, $5 \%-6 \%$ dolomite and $43 \%-47 \%$ aragonite.

Sub-unit $2 b$ is marly chalk at the top of the sub-unit and light gray intraclastic chalk with greenish gray clasts at the bottom. The marly chalk (five samples) consists of $67 \%-72 \%$ calcite, $3 \%-6 \%$ dolomite, $23 \%-28 \%$ aragonite, and $1 \%-2 \%$ quartz. The intraclastic chalk (three samples) has 79\%-85\% calcite, $1 \%-3 \%$ dolomite, $13 \%-18 \%$ aragonite, and $1 \%$ quartz.

Sub-unit $2 \mathrm{c}$ is a middle Miocene dark olive-gray radiolarian mudstone. The four samples of this subunit analyzed show relatively varied mineral contents. In general, the samples range from $16 \%-55 \%$ calcite, $42 \%$ quartz, and $21 \%-36 \%$ clay minerals. Five per cent pyrite was detected in one sample and $14 \%$ feldspar in another (plagioclase 7\%, K-feldspar 7\%). The clay minerals are varied, with palygorskite (21\%-29\%) present in the two samples along with sepiolite (2\%) and montmorillonite (1\%) in one of these. Mica (10\%-20\%) and montmorillonite (8\%-10\%) are present in the other two samples. Kaolinite (2\%-6\%) is present in all four samples.

Sub-unit $2 \mathrm{~d}$ is an intraclastic chalk. Nine samples were analyzed from this sub-unit. Eight of these samples showed $95 \%-98 \%$ calcite, $0 \%-2 \%$ dolomite, and $2 \%-4 \%$ quartz. One Sample (391A-12-6, 45-47 cm), from a turbidite, showed $66 \%$ calcite, $1 \%$ dolomite, $32 \%$ aragonite, and $1 \%$ quartz.

Sub-unit $2 \mathrm{e}$ is a deposit with interbedded mudstones and chalks. The chalks are intraclastic near the base of the unit. Fourteen samples were X-rayed and the compositions fell into four groups. First, chalks and marly chalks (seven samples) are $96 \%-99 \%$ calcite, $1 \%$ $3 \%$ dolomite, and 1\%-3\% quartz. One sample of an intraclastic chalk comprises the second group with $82 \%$ calcite, $2 \%$ dolomite, $11 \%$ aragonite, $3 \%$ quartz, and $2 \%$ montmorillonite. The third group are the mudstones in Core 391 A-13. Two samples showed 53\%-56\% calcite, $3 \%-5 \%$ dolomite, $0 \%-7 \%$ aragonite, $9 \%-10 \%$ quartz, $23 \%-33 \%$ clay minerals (palygorskite 19\%-27\%, sepiolite $4 \%-6 \%$ ), and $0 \%-2 \%$ pyrite. Mudstones and claystones from the rest of the sub-unit compose the fourth group. Four samples show no calcite, 31\%-49\% quartz, $11 \%$ plagioclase in one sample, $46 \%-65 \%$ clay (montmorillonite 19\%-49\%, mica 9\%-19\%, kaolinite $5 \%-6 \%$, chlorite $0 \%-10 \%$ ), and $2 \%-5 \%$ pyrite.

\section{Unit 3}

Unit 3 is a claystone unit of Late Cretaceous to Aptian age. Two sub-units have been distinguished. Sub-unit 3a consists of dark greenish gray, olive-gray, and black claystones. The analysis of 11 samples indicates a composition of $30 \%-58 \%$ quartz, $4 \%-24 \%$ 
TABLE 4

X-Ray Mineralogy Summary, Hole 391

\begin{tabular}{|c|c|c|c|c|c|c|c|c|c|c|}
\hline $\begin{array}{c}\text { Sample } \\
\text { (Interval in } \mathrm{cm} \text { ) }\end{array}$ & $\begin{array}{l}\text { Depth } \\
(\mathrm{m})\end{array}$ & Unit & శ్ర & $\stackrel{\circ}{\circ}$ & 㟧 & $\frac{\dot{2}}{\grave{1}}$ & $\frac{a}{2}$ & $\frac{3}{2}$ & 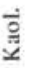 & हैं \\
\hline $1-2,94-96$ & 2.4 & 1 & 32 & 2 & 27 & 8 & 11 & 10 & 4 & 5 \\
\hline
\end{tabular}

feldspars (plagioclase $4 \%-18 \%, \mathrm{~K}$-feldspar $0 \%-9 \%$ ), and $30 \%-57 \%$ clay minerals (mica $17 \%-24 \%$, montmorillonite $0 \%-32 \%$, kaolinite $1 \%-11 \%$, chlorite $1 \%-2 \%)$. Pyrite is sometimes seen (0\%-5\%). One sample shows $2 \%$ calcite.

Sub-unit $3 \mathrm{~b}$ is a dark gray calcareous claystone with sparse interbeds of limestone. Two samples from this sub-unit have a wide variation in mineral percentages. One sample is $85 \%$ calcite, $7 \%$ quartz, $3 \%$ plagioclase, and $5 \%$ montmorillonite. The other sample is $15 \%$ calcite, $34 \%$ quartz, $7 \%$ mica, $19 \%$ montmorillonite, and $25 \%$ pyrite.

\section{Unit 4}

Unit 4 consists of a variety of limestones, mudstones, and shales of (Barremian?) Hauterivian to late Tithonian age. This unit has been divided into four sub-units. Sub-unit $4 a$ is characterized by limestones and mudstones containing, in part, quartz sand and silt. A relatively wide range of mineral composition is found in this sub-unit. A sample of clayey limestone from Core $391 \mathrm{C}-14$ contains $45 \%$ calcite, $22 \%$ quartz, and $33 \%$ clay minerals (mica 18\%, montmorillonite $13 \%$, kaolinite $2 \%$ ). A calcareous claystone in Core 391C-15 contains $59 \%$ calcite, $17 \%$ quartz, $7 \%$ feldspar (K-feldspar $4 \%$, plagioclase $3 \%$ ), and $17 \%$ clay minerals (mica $7 \%$, montmorillonite $7 \%$, kaolinite 3\%). A sandy layer at $391 \mathrm{C}-16-3,129-131 \mathrm{~cm}$ has $39 \%$ calcite, $24 \%$ quartz, and $28 \%$ feldspar ( $\mathrm{K}$-feldspar $24 \%$, plagioclase $14 \%$ ). Two samples of sandy limestone from Cores 391C-17 and 20 show $60 \%-61 \%$ calcite, $16 \%-20 \%$ quartz, and $20 \%-23 \%$ feldspar (K-feldspar $11 \%-12 \%$, plagioclase 9\%-11\%). A calcareous claystone from Core 391C-21 shows $93 \%$ calcite, $3 \%$ quartz, and $4 \%$ mica.

Sub-unit $4 \mathrm{~b}$ is a series of interbedded limestones and shales. The 13 samples analyzed from this sub-unit appear to fall into three groups. The first group consists of 10 limestone samples which contain $94 \%-99 \%$ calcite, $1 \%-4 \%$ quartz, and, in three of these samples, $2 \%-3 \%$ montmorillonite. In the second group two samples of clayey limestone show $77 \%-81 \%$ calcite, $7 \%-8 \%$ quartz, $1 \%-2 \%$ plagioclase, and $9 \%-15 \%$ clay minerals (montmorillonite 5\%-13\%, mica $2 \%-4 \%$ ). One sample of a shale layer falls in the third group with $35 \%$ calcite, $36 \%$ quartz, $2 \%$ plagioclase, and $27 \%$ clay minerals (montmorillonite $17 \%$, mica $8 \%$, kaolinite $2 \%$ ).

Sub-unit $4 \mathrm{c}$ is a limestone unit which four samples show to be $86 \%-97 \%$ calcite, $3 \%-6 \%$ quartz, and $0 \%-8 \%$ montmorillonite.

Sub-unit $4 \mathrm{~d}$ is a limestone with clay stringers. Nine limestone samples show $90 \%-98 \%$ calcite and $2 \%-10 \%$ quartz. Six samples of the clay stringers show a range of $57 \%-84 \%$ calcite, $7 \%-28 \%$ quartz, $0 \%-4 \%$ plagioclase, and $4 \%-12 \%$ clay minerals (mica $0 \%-8 \%$, montmorillonite $2 \%-4 \%$, kaolinite $0 \%-2 \%$ ).
Unit 5

Unit 5 consists of early Tithonian red limestone and calcareous claystone which has been divided into two sub-units. Sub-unit 5a is a group of variegated argillaceous limestones. Five samples of the argillaceous zones show $60 \%-80 \%$ calcite, $14 \%$ aragonite in one sample, $16 \%-22 \%$ quartz, $0 \%-3 \%$ plagioclase, and $7 \%$ $15 \%$ clay minerals (montmorillonite $2 \%-7 \%$, mica $4 \%$ $7 \%$, kaolinite $0 \%-1 \%$ ). Two samples of the limestones show $91 \%-99 \%$ calcite and $1 \%-9 \%$ quartz.

Sub-unit $5 \mathrm{~b}$ consists of a red marl. Four samples indicate $29 \%-58 \%$ calcite, $3 \%-35 \%$ aragonite, $14 \%-17 \%$ quartz, $3 \%-12 \%$ feldspar (plagioclase $3 \%-8 \%, \mathrm{~K}-$ feldspar $0 \%-4 \%$ ), and $9 \%-40 \%$ clay minerals (montmorillonite $4 \%-25 \%$, mica $4 \%-15 \%$, kaolinite $1 \%$ $4 \%)$.

\section{Site 392}

Holes 392 and 392A were drilled on the Blake Nose to penetrate into the Cretaceous reef and examine the sediments above the reef. Four units have been recognized. Table 8 summarizes the $\mathrm{X}$-ray diffraction data from Hole 392A. No samples from Hole 392 were $\mathrm{X}$-rayed.

\section{Unit 1}

Unit 1 is a sequence of Campanian to Barremian nannofossil oozes and nannofossil clays. Core 392A-1 penetrated a nanno ooze. A sample from this core contains $99 \%$ calcite and 1\% quartz. Cores 392A-2 through 3 cored marly nannofossil ooze which contains $58 \%-74 \%$ calcite, $0 \%-10 \%$ aragonite, $9 \%-12 \%$ quartz, $5 \%-8 \%$ feldspar (plagioclase 3\%-5\%, K-feldspar 0\%$4 \%$ ), and $8 \%-15 \%$ clay minerals (mica $5 \%-8 \%$, montmorillonite $3 \%-5 \%$, kaolinite $0 \%-2 \%$ ). Cores 392A-3 through 4 cored nannofossil ooze which showed $88 \%-92 \%$ calcite, $0 \%-2 \%$ dolomite, 3\%-6\% quartz, and $3 \%-6 \%$ feldspar (K-feldspar $2 \%-3 \%$, plagioclase $0 \%-3 \%$ ).

\section{Unit 2}

Unit 2 is a fenestral limestone of unknown age. Two samples of this unit showed it to be $100 \%$ calcite. No samples of units 3 or 4 were analyzed.

\section{Site 394 (Leg 44A)}

Hole 394A was drilled at the location of Site 391 (Leg 44). Six samples from two cores were analyzed during the X-ray diffraction work (Table 9). Cores 394A-5 and 6 appear to be from unit 2 of Miocene age described at Site 391. Two samples from Core 394A-5, a chalk breccia, contain $82 \%-90 \%$ calcite, $1 \%$ dolomite, $9 \%-14 \%$ aragonite, and 1\%-3\% quartz. Three of the samples from Core 394A-6, a marly chalk breccia, has $65 \%-88 \%$ calcite, $1 \%$ dolomite, $9 \%-34 \%$ aragonite, and $0 \%-1 \%$ quartz. One sample (394A-6-6, 90-92 cm) is of a large olive-gray siliceous clay clast and contains $38 \%$ calcite, $26 \%$ quartz, $3 \%$ plagioclase, $29 \%$ clay minerals (palygorskite $20 \%$, montmorillonite $5 \%$, kaolinite $4 \%$ ), and $3 \%$ pyrite. 
TABLE 5

X-Ray Mineralogy Summary, Hole 391A

\begin{tabular}{|c|c|c|c|c|c|c|c|c|c|c|c|c|c|c|c|c|}
\hline $\begin{array}{c}\text { Sample } \\
\text { (Interval in } \mathrm{cm} \text { ) }\end{array}$ & $\begin{array}{l}\text { Depth } \\
\text { (m) }\end{array}$ & Unit & लुँ & $\frac{\circ}{\circ}$ & 迩 & పี & $\frac{1}{4}$ & $\frac{\dot{m}}{\tilde{E}}$ & $\stackrel{\Xi}{\Sigma}$ & $\frac{\dot{J}}{\dot{0}}$ & $\stackrel{\vec{g}}{\simeq}$ & हैं & ओं & हैं & 茨 & E \\
\hline $1-2,123-125$ & 88.7 & 1 & 19 & 2 & - & 31 & 7 & 17 & 8 & 3 & 3 & 6 & - & - & - & \\
\hline $1-5,91-93$ & 92.9 & 1 & 37 & 1 & 11 & 22 & 4 & 8 & 10 & 2 & 3 & 3 & - & - & - & \\
\hline $1-6,116-118$ & 94.7 & 1 & - & 1 & - & 43 & 12 & 18 & 16 & - & 8 & - & - & - & - & \\
\hline $2-2,118-120$ & 34.2 & 1 & 30 & 2 & - & 28 & 11 & 15 & 9 & - & 5 & - & - & - & - & \\
\hline $2-4,104-106$ & 37.1 & 1 & 29 & 1 & - & 30 & 10 & 14 & 12 & - & 4 & - & - & - & - & \\
\hline $3-3,81-83$ & 149.3 & $2 \mathrm{~A}$ & 48 & 5 & 47 & - & - & - & - & - & - & - & - & - & - & \\
\hline $3-5,83-85$ & 152.3 & $2 \mathrm{~A}$ & 52 & 6 & 43 & - & - & - & - & - & - & - & - & - & - & \\
\hline $4-2,104-106$ & 205.1 & 2B & 68 & 6 & 25 & 2 & - & - & - & - & - & - & - & - & - & \\
\hline $4-4,92-94$ & 207.9 & $2 \mathrm{~B}$ & 67 & 3 & 28 & 2 & - & - & - & - & - & - & - & - & - & \\
\hline $5-2,92-94$ & 261.9 & 2B & 72 & 3 & 23 & 2 & - & - & - & - & - & - & - & - & - & \\
\hline $5-4,92-94$ & 264.9 & 2B & 68 & 3 & 26 & 2 & - & - & - & - & - & - & - & - & - & \\
\hline $5-6,85-86$ & 267.9 & 2B & 67 & 3 & 28 & 1 & - & - & - & - & - & - & - & - & - & \\
\hline $6-2,99-101$ & 319.0 & $2 \mathrm{~B}$ & 79 & 2 & 18 & 1 & - & - & - & - & - & - & - & - & - & \\
\hline $6-4,99-101$ & 322.0 & 2B & 81 & 3 & 15 & 1 & - & - & - & - & - & - & - & - & - & \\
\hline $6-5,123-125$ & 323.7 & $2 \mathrm{~B}$ & 85 & 1 & 13 & 1 & - & - & - & - & - & - & - & - & - & \\
\hline $7-1,123-125$ & 327.2 & $2 \mathrm{C}$ & 34 & - & - & 31 & 7 & 7 & 10 & 8 & 3 & - & - & - & - & \\
\hline $7-4,114-116$ & 331.6 & $2 \mathrm{C}$ & 48 & - & - & 21 & - & - & - & - & 2 & - & 29 & - & - & \\
\hline $7-5,92-94$ & 332.9 & $2 \mathrm{C}$ & 55 & - & - & 20 & - & - & - & 1 & 2 & - & 21 & 2 & - & \\
\hline $8-1,118-120$ & 336.7 & $2 \mathrm{C}$ & 16 & - & - & 42 & - & - & 20 & 10 & 6 & - & - & - & 5 & \\
\hline $9-2,86-88$ & 357.0 & 2D & 97 & 1 & - & 2 & - & - & - & - & - & - & - & - & - & \\
\hline $9-4,108-110$ & 360.1 & $2 \mathrm{D}$ & 95 & 1 & - & 3 & - & - & - & - & - & - & - & - & - & \\
\hline $10-4,85-87$ & 378.9 & 2D & 96 & 2 & - & 2 & - & - & - & - & - & - & - & - & - & \\
\hline $10-6,96-88$ & 381.9 & 2D & 97 & 1 & - & 3 & - & - & - & - & - & - & - & - & - & \\
\hline $11-1,80-82$ & 412.3 & 2D & 96 & 1 & - & 2 & - & - & - & - & - & - & - & - & - & \\
\hline $11-4,59-61$ & 416.6 & 2D & 95 & 1 & - & 4 & - & - & - & - & - & - & - & - & - & \\
\hline $12-2,146-148$ & 471.5 & 2D & 96 & 2 & - & 3 & - & - & - & - & - & - & - & - & - & \\
\hline $12-6,45-47$ & 476.5 & 2D & 66 & 1 & 32 & 1 & - & - & - & - & - & - & - & - & - & \\
\hline $12-6,63-65$ & 476.6 & 2D & 98 & - & - & 2 & - & - & - & - & - & - & - & - & - & \\
\hline $13-1,64-66$ & 526.1 & $2 \mathrm{E}$ & 56 & 3 & 7 & 9 & - & - & - & - & - & - & 19 & 4 & 2 & \\
\hline $13-2,93-95$ & 527.9 & $2 \mathrm{E}$ & 96 & 3 & - & 2 & - & - & - & - & - & - & $\overline{0}$ & - & - & \\
\hline $13-5,113-115$ & 532.6 & $2 \mathrm{E}$ & 53 & 5 & - & 10 & - & - & - & - & - & - & 27 & 6 & - & \\
\hline $16-2,87-89$ & 556.4 & $2 \mathrm{E}$ & - & - & - & 41 & - & 11 & 12 & 19 & 5 & 10 & - & - & 2 & \\
\hline $17-2,65-67$ & 565.7 & $2 \mathrm{E}$ & 98 & 1 & - & 1 & - & - & - & - & - & - & - & - & - & \\
\hline $17-4,62-64$ & 568.6 & $2 \mathrm{E}$ & 98 & 1 & - & 1 & - & - & - & - & - & - & - & - & - & \\
\hline $19-1,133-135$ & 583.8 & $2 \mathrm{E}$ & - & - & - & 31 & - & - & 18 & 41 & 6 & - & - & - & 5 & \\
\hline $19-2,85-87$ & 584.9 & $2 \mathrm{E}$ & 96 & 2 & - & 3 & - & - & - & - & - & - & - & - & - & \\
\hline $19-4,128-130$ & 588.3 & $2 \mathrm{E}$ & 99 & - & - & 1 & - & - & - & - & - & - & - & - & $\overline{-}$ & \\
\hline $20-1,90-92$ & 640.4 & $2 \mathrm{E}$ & - & - & - & 31 & - & - & 9 & 49 & 6 & - & - & - & 5 & \\
\hline $20-2,60-62$ & 641.6 & $2 \mathrm{E}$ & - & - & - & 49 & - & - & 19 & 22 & 5 & - & - & - & 5 & \\
\hline $20-4,72-74$ & & $2 \mathrm{E}$ & 82 & 2 & 11 & 3 & - & - & - & 2 & - & - & - & - & - & \\
\hline $21-1,57-59$ & 649.6 & $3 \mathrm{~A}$ & - & - & - & 41 & 6 & 11 & 28 & - & 10 & - & - & - & 5 & \\
\hline $21-3,58-60$ & 652.6 & $3 \mathrm{~A}$ & - & - & - & 42 & - & 4 & 27 & 15 & 11 & - & - & - & - & \\
\hline $21-5,62-64$ & 655.6 & $3 \mathrm{~A}$ & - & - & - & 44 & 4 & 5 & 22 & 17 & 7 & - & - & - & - & \\
\hline
\end{tabular}

\section{DISCUSSION AND CONCLUSIONS}

Carbonates occur frequently throughout the sections cored; calcite is ubiquitous. Dolomite is commonly lower Aptian-Barremian age at Site 392 (Blake Nose). Siderite is found (up to $30 \%$ ), sometimes associated with hematite, in the gas-bearing Miocene sediments at Site 388 (lower continental rise hills). Aragonite is quite common (up to 47\%) in sediments from Sites 391 (Blake-Bahama Basin) and 392 (Blake Nose).

Aragonite, present in the Quaternary sediments and in the Miocene turbidite sequences at Sites 391 and 394 (Blake-Bahama Basin), indicates the contribution of aragonitic sediments from nearby shallow-water carbonate platforms where aragonite is abundant (Hathaway, 1972). This contribution is probably from turbidity currents. Aragonite is also present at this site in the argillaceous zones of sub-unit 5a and throughout sub-unit 5b (early Tethonian) where shipboard scientists found aragonitic fossils. These sediments may have been deposited above the aragonite compensation depth. Some aragonite is also present in Site 392 (Blake Nose) in the early Albian-late Aptian marly nannofossil oozes.

Silicate minerals are quite abundant in these sediments. Quartz (up to 66\%) is, except in three units, present (up to 6\%) in unit 1 of Site 388 (lower continental rise hills), units 1 and 2 of Sites 391 and 394 always present. Feldspars (up to $30 \%$ ) and clay minerals (up to 60\%) are often present. Amphibole (up to 3\%) was found only in the Quaternary sediments of Sites 388 (lower continental rise hills) and 391 (BlakeBahama Basin). The zeolite clinoptilolite (up to $1 \%$ ) was found in three units of Site 390 (Blake Nose).

Plagioclase is, in general, the dominant feldspar. However, K-feldspar is dominant in three units or sub-units of Cretaceous age. At Site 391 (BlakeBahama Basin) $\mathrm{K}$-feldspar is dominant in the sandy limestones and in a calcareous claystone of sub-unit 4a (Barremian?, Hauterivian to late Valaginian). On the 
TABLE 6

X-Ray Mineralogy Summary, Hole 391B

\begin{tabular}{|c|c|c|c|c|c|c|c|c|c|c|c|c|c|}
\hline $\begin{array}{c}\text { Sample } \\
\text { (Interval in } \mathrm{cm} \text { ) }\end{array}$ & $\begin{array}{l}\text { Depth } \\
\text { (m) }\end{array}$ & Unit & లुँ & $\stackrel{\circ}{\circ}$ & 氙 & 这 & $\frac{a}{a}$ & 疍 & 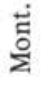 & : & อิ & ᄅं & 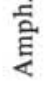 \\
\hline $1-2,91-93$ & 2.4 & 1 & 19 & 4 & 24 & 7 & 9 & 26 & 2 & 8 & 2 & - & 1 \\
\hline $1-4,117-119$ & 5.7 & 1 & 12 & 3 & 33 & 6 & 13 & 22 & - & 8 & - & - & 2 \\
\hline $1-6,95-97$ & 8.5 & 1 & 17 & 1 & 30 & 13 & 26 & 9 & - & 2 & - & 1 & 2 \\
\hline
\end{tabular}

TABLE 7

X-Ray Mineralogy Summary, Hole 391C

\begin{tabular}{|c|c|c|c|c|c|c|c|c|c|c|c|c|c|}
\hline $\begin{array}{c}\text { Sample } \\
\text { (Interval in cm) }\end{array}$ & $\begin{array}{l}\text { Depth } \\
\text { (m) }\end{array}$ & Unit & तี & $\frac{0}{0}$ & 坣 & 氛 & 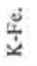 & 离 & $\frac{\pi}{\Sigma}$ & 产 & $\begin{array}{l}\dot{0} \\
\check{g}\end{array}$ & $\frac{\dot{O}}{\mathrm{E}}$ & $\stackrel{2}{2}$ \\
\hline $2-1,2-4$ & 611.0 & $2 \mathrm{E}$ & 96 & 1 & - & 3 & - & - & - & - & - & 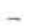 & \\
\hline $2-3,120-12$ & 615 & $2 \mathrm{E}$ & 97 & 1 & - & 2 & - & 1 & - & - & - & 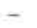 & - \\
\hline $4-1,90-92$ & 668.9 & $3 \mathrm{~A}$ & - & - & - & 53 & 7 & 6 & 17 & 13 & 4 & - & - \\
\hline $5-1,99-101$ & 678.5 & $3 \mathrm{~A}$ & - & - & - & 58 & - & 13 & 24 & - & 6 & - & - \\
\hline $6-4,104-106$ & 692.6 & $3 \mathrm{~A}$ & - & - & - & 48 & 8 & 15 & 18 & 3 & 5 & 2 & - \\
\hline $7-2,60-62$ & 727.1 & $3 \mathrm{~A}$ & 2 & - & - & 30 & 6 & 11 & 21 & 27 & 3 & - & - \\
\hline $8-2,31-33$ & 783.8 & $3 \mathrm{~A}$ & 2 & - & - & 29 & 5 & 7 & 21 & 32 & 4 & - & 2 \\
\hline $9-1,112-114$ & 830.6 & $3 \mathrm{~A}$ & - & - & - & 45 & - & 18 & 19 & 12 & 5 & - & - \\
\hline $10-2,132-134$ & 898.8 & $3 \mathrm{~A}$ & - & - & - & 41 & 8 & 16 & 23 & 9 & 2 & - & - \\
\hline $10-3,70-72$ & 899. & $3 \mathrm{~A}$ & - & - & - & 45 & 9 & 12 & 19 & 13 & 1 & - & - \\
\hline $11-3,108-110$ & 928 & $3 \mathrm{~B}$ & 85 & - & - & 7 & - & 3 & - & 5 & - & - & - \\
\hline $12-1,63-65$ & 935.6 & 3B & 15 & - & - & 34 & - & - & 7 & 19 & - & - & 25 \\
\hline $14-1,122-124$ & 1001.7 & $4 A$ & 45 & - & - & 22 & - & - & 18 & 13 & 2 & - & - \\
\hline $15-1,127-129$ & 1011.3 & $4 \mathrm{~A}$ & 59 & - & - & 17 & 4 & 3 & 7 & 7 & 3 & - & - \\
\hline $16-3,129-131$ & 1023. & $4 \mathrm{~A}$ & 39 & - & - & 24 & 24 & 14 & - & - & - & - & - \\
\hline $17 \cdot 2,94-95$ & 1031. & $4 \mathrm{~A}$ & 60 & - & - & 20 & 11 & 9 & - & - & - & - & - \\
\hline $20-1,112-114$ & 1058 & $4 \mathrm{~A}$ & 61 & - & - & 16 & 12 & 11 & - & - & - & - & - \\
\hline $21-4,110-1$ & 1091 & $4 \mathrm{~A}$ & 93 & - & - & 3 & - & - & 4 & - & - & - & - \\
\hline $24-2,60-62$ & 1126.1 & $4 \mathrm{~B}$ & 99 & - & - & 1 & - & - & - & - & - & - & - \\
\hline $25-2,91-5$ & 1135.9 & $4 \mathrm{~B}$ & 9 & - & - & $i$ & - & - & - & - & - & - & _- \\
\hline $26-2,82-83$ & 1145.3 & $4 \mathrm{~B}$ & 98 & - & _- & 2 & - & - & - & - & - & - & - \\
\hline $26-4,9$ & 1 & $4 B$ & 97 & - & - & 3 & - & - & - & - & - & - & - \\
\hline $27-4,6$ & 1157. & $4 \mathrm{~B}$ & 35 & - & - & 36 & - & 2 & 8 & 17 & 2 & - & - \\
\hline $27-4$ & 1157 & $4 \mathrm{~B}$ & 96 & - & - & 2 & - & - & - & 2 & - & - & - \\
\hline $28-4,6$ & 1167 & $4 \mathrm{~B}$ & 96 & - & - & 2 & - & - & - & 2 & - & - & - \\
\hline $29-3$ & 1175 & 4 & 94 & - & - & 2 & - & - & - & 3 & - & - & - \\
\hline $30-4$ & 1186 & & 98 & - & - & 2 & - & - & - & - & - & - & - \\
\hline $31-2,6$ & 1192 & $4 B$ & 99 & - & - & 1 & - & - & - & - & - & - & - \\
\hline $31-6,8$ & 11 & 4 & 81 & - & - & 8 & - & 2 & 4 & 5 & - & - & - \\
\hline $144-145$ & 1202.9 & $4 \mathrm{~B}$ & 77 & - & - & 7 & - & 1 & 2 & 13 & - & 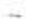 & - \\
\hline $33-3$ & 1213.1 & $4 B$ & 96 & - & - & 4 & - & - & - & - & - & - & - \\
\hline $34-4,61-63$ & 1224.1 & $4 \mathrm{C}$ & 93 & - & - & 4 & - & - & - & 3 & - & - & - \\
\hline $35-2$ & 12 & $4 \mathrm{C}$ & 86 & - & - & 6 & - & - & - & 8 & - & - & - \\
\hline $36-4$ & 1243 & & 91 & - & - & 5 & - & - & - & 4 & - & - & - \\
\hline $37-2$ & 1250 & $4 \mathrm{C}$ & 97 & - & - & 3 & - & - & - & - & - & - & - \\
\hline $38-1,1$ & 12 & 4 & 95 & - & - & 5 & - & - & - & - & - & - & - \\
\hline & 126 & 4D & 98 & - & - & 2 & - & - & - & - & - & - & - \\
\hline $39-2,1$ & 1269.2 & 4D & 84 & - & - & 7 & - & - & 4 & 4 & 2 & - & - \\
\hline & 127 & 4D & 97 & - & - & 3 & - & - & - & - & - & - & - \\
\hline $39-5$ & 1272 . & 4D & 79 & - & - & 12 & - & 3 & 3 & 2 & 1 & - & - \\
\hline & & & 73 & - & - & 19 & - & - & 4 & 3 & 1 & - & - \\
\hline 161 & 1285 & $4 \mathrm{D}$ & 90 & - & - & 10 & - & - & - & - & - & - & - \\
\hline & 12 & 4D & 96 & - & - & 4 & - & - & - & - & - & - & - \\
\hline & & & 9 & - & - & 4 & - & - & - & - & - & - & - \\
\hline $43-3,1$ & & $4 \mathrm{D}$ & 96 & - & - & 4 & - & - & - & - & - & - & - \\
\hline 43-4 & & 4D & 57 & - & - & 28 & - & 4 & 8 & 2 & 2 & - & - \\
\hline $44-2,7$ & 1316 & $4 \mathrm{D}$ & 93 & - & - & 7 & - & - & - & - & - & - & - \\
\hline & 1315 & $4 \mathrm{D}$ & 88 & - & - & 8 & - & - & - & 4 & - & - & - \\
\hline & & & 95 & - & - & 5 & 7 & - & - & - & - & - & - \\
\hline $45-1,137-139$ & 1324 & 4D & 69 & - & - & 22 & - & 1 & 3 & 3 & 1 & - & - \\
\hline & & 5 & 91 & - & - & 9 & - & - & - & - & - & - & - \\
\hline $46-1,72-74$ & 1333.7 & $5 \mathrm{~A}$ & 80 & - & - & 13 & - & - & 5 & 2 & - & - & - \\
\hline $46-1,128-130$ & & $5 \mathrm{~A}$ & 63 & - & - & 22 & - & 3 & 5 & 7 & - & - & - \\
\hline & & $5 \mathrm{~A}$ & 68 & - & - & 16 & - & 1 & 7 & 7 & 1 & - & - \\
\hline $31-133$ & 1354 & SA & 57 & - & 14 & 17 & - & 2 & 4 & 4 & 1 & - & - \\
\hline & & $5 \mathrm{~A}$ & 66 & - & - & 20 & - & 2 & & 4 & - & - & \\
\hline $49-2,99-101$ & & $5 \mathrm{~A}$ & 99 & - & - & 1 & - & 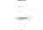 & - & - & - & - & . \\
\hline & & & 58 & - & 3 & 17 & - & 3 & 9 & 10 & - & - & - \\
\hline $114-116$ & & $5 \mathrm{~B}$ & 38 & - & 35 & 14 & - & 4 & 4 & 4 & 1 & - & $=$ \\
\hline & & $5 B$ & 39 & - & 10 & 15 & - & 5 & 15 & 15 & 4 & - & $=$ \\
\hline $52-4,73-75$ & 1395.2 & $5 B$ & 29 & - & 4 & 15 & 4 & 8 & 13 & 25 & 2 & - & \\
\hline
\end{tabular}

Blake Nose, K-feldspar is dominant in the late AptianBarremian nannofossil ooze of Site 392 and is the only feldspar present in the Maestrichtian nannofossil oozes (unit 5) of Site 390.

Mica or montmorillonite are often the dominant clay mineral of these samples with kaolinite usually present in lesser amounts. Two areas of interest were delineated on the basis of clay minerals.

Chlorite occurs scattered throughout the Pleistocene and Miocene of Site 388 (lower continental rise hills)
TABLE 8

X-Ray Mineralogy Summary, Hole 392A

\begin{tabular}{|c|c|c|c|c|c|c|c|c|c|c|c|}
\hline $\begin{array}{c}\text { Sample } \\
\text { (Interval in } \mathrm{cm} \text { ) }\end{array}$ & $\begin{array}{l}\text { Depth } \\
(\mathrm{m})\end{array}$ & Unit & हैं & $\stackrel{\circ}{\circ}$ & 崑 & 递 & 芒 & $\frac{a}{20}$ & $\frac{\mathscr{2}}{\Sigma}$ & $\frac{\dot{0}}{\dot{\Sigma}}$ & 苛 \\
\hline $118-120$ & & 1 & 99 & - & - & 1 & - & - & - & - & \\
\hline & & 1 & 58 & - & 10 & 12 & - & 5 & 8 & 5 & 2 \\
\hline $2-3$ & & 1 & 74 & - & - & 10 & 4 & 4 & 5 & 3 & \\
\hline $3-1,102-104$ & 80.0 & 1 & 68 & - & 5 & 9 & 2 & 3 & 5 & 5 & 2 \\
\hline & & 1 & 92 & 2 & - & 3 & 2 & 1 & - & - & \\
\hline $3-3,111-113$ & 83.1 & 1 & 92 & 1 & - & 4 & 3 & - & - & - & - \\
\hline & & 1 & 88 & - & - & 6 & 3 & 3 & - & - & - \\
\hline $5-1,145-147$ & 99.5 & 2 & 100 & - & - & - & - & - & - & - & - \\
\hline $6-1,131-132$ & 108.8 & 2 & 100 & - & - & - & - & - & - & - & - \\
\hline
\end{tabular}

TABLE 9

X-Ray Mineralogy Summary, Hole 394A

\begin{tabular}{|c|c|c|c|c|c|c|c|c|c|c|c|}
\hline $\begin{array}{c}\text { Sample } \\
\text { (Interval in } \mathrm{cm} \text { ) }\end{array}$ & $\begin{array}{l}\text { Depth } \\
\text { (m) }\end{array}$ & Unit & तु & $\stackrel{\circ}{\circ}$ & 荧 & है & $\frac{\text { mi }}{2}$ & $\frac{\tilde{5}}{2}$ & 官 & $\frac{\lambda}{\sqrt{n}}$ & $\frac{1}{2}$ \\
\hline $5-1,70-73$ & 279.7 & 2 & 82 & 1 & 14 & 3 & - & - & - & - & - \\
\hline $5-3,113-116$ & 283.1 & 2 & 90 & 1 & 9 & 1 & - & - & - & - & - \\
\hline $6-1,90-92$ & 355.9 & 2 & 70 & 1 & 28 & 1 & - & - & - & - & - \\
\hline $6-3,90-92$ & 358.9 & 2 & 65 & 1 & 34 & - & - & - & - & - & - \\
\hline $6-4,90-92$ & 360.4 & 2 & 88 & 1 & 9 & 1 & - & - & - & - & - \\
\hline $6-6,90-92$ & 363.4 & 2 & 38 & - & - & 26 & 3 & 5 & 4 & 20 & 3 \\
\hline
\end{tabular}

and in the Quaternary, early Miocene, and Late Cretaceous of Site 391 (Blake-Bahama Basin). Amphibole occurs only in the Quaternary sediments of these sites. Chlorite and amphibole are part of Hathaway's (1972) northern mineral assemblage and indicate a northern (north of Cape Hatteras) provenance for the Quaternary sediments of these sites. At Site 391, deep, southward-flowing contour currents have carried these minerals to their present position south of Cape Hatteras (Tucholke, 1975; Hathaway, 1972). The northern mineral assemblage-a result of glacial erosion of Paleozoic and older sedimentary and metamorphic rocks of the northern Appalachian region-contains illite, chlorite, finely divided quartz, feldspar, and accessory minerals such as hornblende. As such, this mineral assemblage is a valid indicator of a northern source only after the onset of North American continental glaciation, approximately three million years ago.

Palygorskite and sepiolite are present in the middle Miocene radiolarian mudstone (sub-unit 2c), in the early Miocene mudstone (sub-unit 2e) of Site 391 (Blake-Bahama Basin), and in a clast from the Miocene sediments drilled at Site 394 (Blake-Bahama Basin). The presence of palygorskite and sepiolite of Miocene age was also detected at Site 12 (DSDP Leg 2, Cape Verde Basin, Peterson et al., 1970); in drill holes on the Florida continental margin (Hathaway et al., 1970); and in rocks of the southern coastal plain (Gremillion, 
1965). Gremillion (1965) concluded that the Miocene palygorskite and sepiolite of Florida, Georgia, and South Carolina formed from the lateration of volcanic ash in a nearshore marine environment. The palygorskite and sepiolite found at Site 391 could either have formed in place in the deep sea, as may be indicated by the mudstones of sub-units $2 \mathrm{c}$ or $2 \mathrm{e}$, or they could have slumped in from shallower sedimentary environments, as may be indicated by the sediments cored at Site 394.

Clinoptilolite is present in the middle Eocene to late Paleocene samples of Site 390 (Blake Nose). Clinoptilolite has previously been found in Oligocene to Paleocene sediments sampled by drill holes on the Florida continental margin (Hathaway et al., 1970). Hathaway et al. (1970) discuss the origin of clinoptilolite as an alteration product of volcanic ash. They also discuss other lower Tertiary occurrences of volcanic ash and its alteration products on the Gulf Coastal Plain and in Alabama, Mississippi, and Texas.

Pyrite (up to 24\%) is often present in the clays, claystones, and mudstones of Site 388 (lower continental rise hills) and Sites 391 and 394 (BlakeBahama Basin). Hematite (0\%-3\%) was scattered throughout the Site 388 sediments (lower continental rise hills).

\section{ACKNOWLEDGMENTS}

Drs. Frederick Sayles and John Hathaway kindly allowed me to use their X-ray diffraction units. Dr. P.D. Johnson provided information on the appropriate techniques and Ms. Robin Hollister and Messers. Peter George and Ned
Goddard aided substantially in the sample preparation. During this project, the author was supported by the Massachusetts Institute of Technology-Woods Hole Oceanographic Institution Joint Program in Oceanography. Dr. C.D. Hollister critically reviewed the manuscript.

\section{REFERENCES}

Cook, H.E., Johnson, P.D., Matti, J.C., and Zemmels, I., 1975. Methods of sample preparation and X-ray diffraction analysis, X-ray Mineralogy Laboratory, Deep Sea Drilling Project, University of California, Riverside. In Hayes, D.E., Frakes, L.A., et al., Initial Reports of the Deep Sea Drilling Project, Volume 28: Washington, D.C. (U.S. Government Printing Office), p. 999-1007.

Gremillion, L.R., 1965. The origin of attapulgite in the Miocene strata of Florida and Georgia: Ph.D. thesis, Florida State University, Tallahassee.

Hathaway, J.C., 1972. Regional clay mineral facies in estuaries and continental margin of the United States East Coast: Geol. Soc. Am. Mem. 133, p. 293-316.

Hathaway, J.C., McFarlin, P.F., and Ross, D.A., 1970. Mineralogy and origin of sediments from drill holes on the Continental margin off Florida: U.S. Geol. Surv. Prof. Paper 581-E, p. I-26.

Peterson, M.N.A., et al., 1970. Initial Reports of the Deep Sea Drilling Project, Volume 2: Washington (U.S. Government Printing Office).

Tucholke, B.E., 1975. Sediment distribution and deposition by the Western Boundary Undercurrent: The Greater Antilles Outer Ridge: J. Geol., v. 83, p. 177-207.

Zemmels, I. and Cook, H.E., 1976. X-ray mineralogy from the Nazca Plate-Leg 34 Deep Sea Drilling Project. In Yeats, R.S., Hart, S.R., et al., Initial Reports of the Deep Sea Drilling Project, Volume 34: Washington (U.S. Government Printing Office), p. 3-7. 